\title{
"Sosiologia ON KAMPPAILULAJi"
}

La sociologie est un sport de combat. Un film de Pierre Carles sur Pierre Bourdieu, en partenariat avec le Monde diplomatique. C-P Productions et VF Films, France. $150 \mathrm{~min} / \mathrm{DVD} / 2007$.

Pierre Carlesin dokumenttielokuva Pierre Bourdieustä (1930-2002) La sociologie est un sport de combat tuli Ranskassa elokuvateatteriin 2. toukokuuta 2001 ja oli ainakin Pariisissa jonkinmoinen menestys dokumenttielokuvaksi. Televisiossa sitä ei ole koskaan esitetty. Vuonna 2004 se julkaistiin VHF-videona (secam-standardilla, mikä vaikeutti sen katsomista esimerkiksi Suomessa) ja viime joulukuussa 2007 DVD:nä (yhteistyössä Le Monde diplomatique -lehden kanssa). Siinä on nyt myös englannin-, espanjan- ja portugalinkielinen tekstitys.

Carlesin dokumenttielokuva herätti heti ensi-iltansa jälkeen toukokuussa 2001 verraten suurta huomiota Ranskassa, ja siitä ilmestyi hetimiten arvostelut muun muassa sellaisissa lehdissä kuin Le Monde, Libération, Télérama ja Le Monde diplomatique. Eräät arvostelijat huomauttivat ironisesti siitä että Bourdieu - joka oli esiintynyt hyvin mediakriittisenä ja arvostellut "mediaintellektuelleja" (vrt. kirja Televisiosta, josta on julkaistu myös Bourdieun luennot Collège de France'ssa DVD:nä) - nyt vaatimattomana henkilönä oli suostunut vieläpä poikkeuksellisen pitkän, kaksi ja puoli tuntisen dokumenttielokuvan päähenkilöksi. (Carles on tosin kertonut, että Bourdieu suostui elokuvaan vasta pitkien suostuttelujen jälkeen.) Toisaalta Bourdieusta oli 1990- luvun jälkipuoliskolla tullut Ranskassa - tahtoen tai tahtomattaan - "mediaintellektuelli”, joka oli esillä suuressa julkisuudessa enemmän kuin koskaan aiemmin. Sen lisäksi, että hän itse osallistui lukuisiin debatteihin ranskalaisissa päivälehdistä, hän osoitti mielenosoituksissa tukensa erilaisille sosiaalisille liikkeille kuten työttömien liikkeelle.

Joissakin arvosteluissa pohdittiin myös sitä, oliko dokumentissa kyse kritiikittömästä henkilöpalvonnasta. Toisaalta todettiin, että sitä voisi pitää jopa "propagandafilminä"; toisaalta kuitenkin myönnettiin ettei se tässä tapauksessa ollut iso ongelma: dokumentti maalaa varsin rehelliseltä vaikuttavan ja monipuolisen, jopa särmikkään muotokuvan Bourdieustä. Toki se on affirmatiivinen, myötäkarvainen, muttei suinkaan mikään ihailijakerhon fanitus - eikä liioin tosikkomainenkaan, vaan paikoin hauskakin, joten se ei ole pituudestaan huolimatta puuduttava ainakaan aiheesta kiinnostuneelle.

Pierre Carles seurasi kuvausryhmän kanssa kolmen vuoden ajan, 1998-2001, Pierre Bourdieun työskentelyä. Dokumentista saa hyvän kuvan, mitä kaikkea hieman väsyneen oloinen - ilmeisesti jo sairas (k. 23. tammikuuta 2002) - 70-vuotias sosiologiintellektuelli viimeisinä vuosinaan teki. Bourdieun ajatteluun perehtynytkin jopa hämmästyy, kuinka johdonmukainen Bourdieu oli sekä ajattelussaan että toiminnassaan ja kuinka hänellä oli vahvasti oma tyyli - intellektuaalinen habitus.

Dokumentti on ennen muuta kuvaus Bourdieun työstä ja ajattelusta sekä hänen osallistuvasta toiminnastaankin. Sii- nä ei lainkaan valoteta hänen yksityiselämäänsä, mutta Bourdieu kertoo parissa haastattelussa itseanalyyttisesti elämäkerrastaan. Dokumentissa on kaksikymmentä jaksoa: Bourdieu antaa haastatteluja, osallistuu paneelikeskusteluihin; Bourdieu työhuoneessaan Collège de France'ssa; sanailee sihteeriensä kanssa; luennoi (muun muassa viimeiset massayleisöluennot Collège de France'ssa), matkustaa (muun muassa Barcelona, Bryssel), neuvottelee "uusliberalismin indikaattoreista" tutkimusryhmänsä kanssa Maison des Sciences de l'Homme -laitoksessa; osallistuu Saksassa TVkeskusteluun Günther Grassin kanssa; läksyttää Loïc Wacquantia siitä kuinka pitää pitää tiukkoja deadlineja ja julkaista kirjoja, ei artikkeleita eikä matkustella! Ja niin edelleen.

Bourdieun persoonaa kuvaa mainio, joskin hieman lavastetun tuntuinen kohtaus hänen työhuoneessaan, kun hän saa kuriiripostina "ystävältään" elokuvaohjaaja JeanLuc Godardilta kirjeen, joka käsittele Godardin Histoire(s) du Cinéma-dokumenttia. Bourdieu lukee kirjeen ja puistelee päätään: "En ymmärrä tästä mitään", ja selittää: "en ole runoilija."

Pierre Bourdieu esitetään dokumentissa sekä sosiologina että militanttina intellektuellina. Hän puhuu sosiologiasta, kommentoi feminismiä - ja Foucault'n homoseksuaalisuutta. Bourdieu käsittelee monia sosiologiastaan tuttuja teemoja, pitäen välillä eräänlaisia pienoisluentoja, aiheinaan muun muassa kulttuuripääoma, La Domination masculine, La Misère du monde, auto- ja sosioanalyysi sekä kertoo muun muassa lingvistisestä kompetenssista, henki- 
lökohtaisesta murretraumastaan: ranskan kielen oikean aksentin puutteesta, ahdistuksesta ja nöyryytyksestä astuessaan akateemiseen maailmaan - mitä suomalaisen asiaan vihkiytymättömän voi olla vaikea käsittää.

Elokuva alkaa Chicagon yliopistoon välitettävällä videokonferenssilla Edward Saidin kanssa; Bourdieu joutuu puhumaan englanniksi, mikä on hänelle raskasta. Sitten siirrytään Jose Bovén johtamaan globalisaationvastaiseen mielenosoitukseen, jossa Bourdieu on osoittamassa solidaarisuuttaan tapansa mukaan sosiaaliselle liikkeelle; mistä seuraa vitsikäs fanitapaaminen kadulla nuorehkon naisen kanssa, joka ei monologiltaan anna suunvuoroa Bourdieulle.

Tämän jälkeen siirrytään antamaan haastattelu Pariisin ulkopuolella Val Fourrén (Mantes-la-Jolie) niin sanotun ongelmalähiön (vrt. lähiömellakat) paikallisradiolle Radio Droit de Citélle, FM
95,5. Kaksi nuorta maahanmuuttajataustaista toimittajaa tivaa Bourdieulta: mitä sosiologia on, mitä se palvelee? Bourdieu yrittää olla kärsivällisen opettavainen. Tässä yhteydessä hän toteaa, että sosiologia on "kamppailulaji": "Se on itsepuolustuksen instrumentti. Se on siis laji, jota käytetään olennaisesti itsepuolustukseen eikä sen harjoittajalla ole oikeutta käyttää sitä väärin.”

Kaikkien jo edellä mainittujen episodien jälkeen dokumentti huipentuu pitkään loppujaksoon Val Fourrén lähiön kulttuuritalossa järjestetystä paneelikeskustelusta, jossa Bourdieu kohtaa osittain jopa vihamielisen yleisön ja joutuu paikallisten asukkaiden kovaan löylytykseen myöhään illalla (keskustelu päättyy klo 23!). Bourdieu kritisoi yleisön anti-intellektualismia ja yrittää valaa optimismia, järjestäytymistä sosiaaliseksi liikkeeksi. Hän replikoi tylysti: "Intellektuellina oleminen ei ole sairaus." Tilaisuuden jo päätyttyä Bourdieu toteaa paikallisille isännilleen: "Jos polttaa autoja, niin niitä pitää polttaa jonkin asian vuoksi."

Lopuksi elokuva palaa alun Chicagon videokonferenssiin: lähikuva Pierre Bourdieustä, joka on väsynyt ja peittää kasvonsa käsiinsä, näkyy vain ryppyinen vanhan miehen otsa...

Tällainen lajissaan harvinainen dokumenttielokuva yhdestä viime vuosikymmenien merkittävimmästä sosiologista on jo sinänsä merkittävä ja mielenkiintoinen tapaus. Se on myös käyttökelpoinen esimerkiksi sosiologian opetuksessa, tasolla jossa opiskelijat ovat jo tutustuneet Bourdieun teksteihin. Olettaen että tekijänoikeudet eivät estä sen esittämistä opetustarkoituksessa.

DVD on tilattavissa osoitteesta: http://boutique.mondediplomatique.fr/boutique/ liste_rayons.cfm.

Keijo Rahkonen 